Bromfield, S. M. (1954). J. gen. Microbiol. 11, 1-6.

\title{
Reduction of Ferric Compounds by Soil Bacteria
}

\author{
BY S. M. BROMFIELD \\ Microbiology Department, Rothamsted Experimental Station, Harpenden, \\ Hertfordshire
}

SUMMARY: Reduction of ferric lactate by washed cell suspensions of Bacillus circulans, B. megaterium and Aerobacter aerogenes takes place in the presence of suitable hydrogen donors. Ferric hydroxide is reduced when $\alpha \alpha^{\prime}$-dipyridyl is present in the cell + substrate system. The reduction of ferric compounds by washed cells + substrate is similar to the reduction of methylene blue. Culture fluids of $\boldsymbol{B}$. circulans do not reduce ferric iron in the absence of normal cells.

The reduction of ferric compounds by soil bacteria is well established, although the mechanism by which the reduction is brought about is still not understood. Halvorson \& Starkey (1927) concluded that the solution and reduction of iron by bacteria was the result of an increase in hydrogen-ion concentration due to acid formation during the decomposition of organic matter and also to the removal of oxygen by metabolic processes. It was considered that the net effect of these changes was to displace the equilibrium between ferrous and ferric iron towards the formation of ferrous iron. Roberts (1947) attempted to discover how strains of Bacillus polymyxa could rapidly reduce ferric hydroxide in glucose media. This was done by studying the dissimilation of glucose under anaerobic conditions; but from the results obtained it was not possible to suggest a mechanism for the reduction. It was found that resting cells of $\boldsymbol{B}$. polymyxa in phosphate buffer and glucose reduced ferric hydroxide, and therefore it was suggested that either a 3-carbon intermediate or formic acid or hydrogen was the hydrogen-donor involved in the reduction. However, it was noted that ferric hydroxide was not reduced when glucose was replaced by formate or hydrogen in resting cell experiments. Bloomfield $(1951,1953)$ studied iron reduction in relation to gley and podzol formation, and found that sterile solutions of fermented grass and water extracts of Kauri pine leaves and bark reduced ferric iron. He advanced the view that the reduction of ferric ions by bacteria may be only a side reaction of the fermentation. Bétrémieux (1951) suggested that the medium became reducing because bacteria removed molecular oxygen, and that when this had taken place other sources of oxygen such as oxides of iron and manganese were used. The work of Bromfield (1954) indicated that the reduction of iron oxide is not, in fact, due to a bacterial utilization of the oxygen of ferric oxide to metabolize a substrate, as is the case when nitrate and sulphate are reduced by certain microorganisms. The work described below is a continuation of earlier work (Bromfield, 1954), and was undertaken to correlate the views of various workers and to elucidate the mechanism by which iron compounds are reduced by bacteria. 


\section{METHODS}

The following media were used:

Medium A. $\mathrm{KH}_{2} \mathrm{PO}_{4}, 0.05$ g.; $\mathrm{MgSO}_{4} .7 \mathrm{H}_{2} \mathrm{O}, 0.02 \mathrm{~g} . ;\left(\mathrm{NH}_{4}\right)_{2} \mathrm{SO}_{4}, 0.1 \mathrm{~g}$., sucrose, 0.5 g.; $\mathrm{CaCO}_{3}, 0.5 \mathrm{~g}$; Difco yeast extract, $0.015 \mathrm{~g}$.; distilled water, $100 \mathrm{ml}$.; adjusted to $\mathrm{pH} \mathbf{7 \cdot 0}$.

Medium $B$. This medium was identical with medium $\mathbf{A}$ except for sucrose, 1.0 g.; Difco yeast extract, $0 \cdot 3 \mathrm{~g}$.; and it was solidified with $2 \%(\mathrm{w} / \mathrm{v})$ agar. Both media were sterilized by autoclaving for $15 \mathrm{~min}$. at $15 \mathrm{lb}$./sq.in.

Total iron was determined by the method of Piper (1942). Ferrous iron was determined directly by means of $\alpha \alpha^{\prime}$-dipyridyl on centrifuged samples of the culture fluids.

Washed bacterial cells were prepared from 24 to $48 \mathrm{hr}$. cultures grown on medium B in Roux bottles at $30^{\circ}$; the period of incubation depended on the rate of growth of the given organism. The cells were suspended in distilled water, centrifuged, resuspended in distilled water and allowed to stand in a shallow layer in flasks at $4^{\circ}$ for $18 \mathrm{hr}$. The suspensions were then centrifuged and the cells resuspended in distilled water. Cells prepared in this way did not completely decolorize methylene blue in 1-2 hr. unless a suitable substrate was added. The washed cells were used as soon as they were prepared as described above.

Reduction of methylene blue and of iron compounds by washed cells was studied in Thunberg tubes, after the method of Quastel, Stephenson \& Whetham (1925). The tubes contained $1 \mathrm{ml}, 0.01 \mathrm{M}$-substrate, $2 \mathrm{ml}$. distilled water, c. $10 \mathrm{mg}$. calcium carbonate and $1 \mathrm{ml}$. methylene blue solution (1 mg./6 ml. water) or $1 \mathrm{ml}$. suspension or solution of the required iron compound. The calcium carbonate was used instead of $0.2 \mathrm{M}$-phosphate buffer because reduction of iron by growing cultures was originally studied in media of high calcium carbonate and low phosphate concentrations. The Thunberg tubes were evacuated for $5 \mathrm{~min}$. at a vacuum of $2-5 \mathrm{~mm}$. $\mathrm{Hg}$, the contents mixed and incubated in a water-bath at $40^{\circ}$; the time necessary for reduction to occur was then noted.

\section{RESULTS}

Solution and reduction of iron compounds by culture fluids of Bacillus circulans To determine whether Bacillus circulans reduced iron by forming reducing substances which accumulated in the culture, the following experiment was carried out: $25 \mathrm{ml}$. vol. of medium $A$ in $6 \times 1$ in. test-tubes were inoculated with $B$. circulans and incubated aerobically at $30^{\circ}$ for 5 days; the cultures were then either autoclaved, treated with $1 \mathrm{ml}$. chloroform, centrifuged or left untreated. To these cultures $1 \mathrm{ml}$. of $1 \%(\mathrm{w} / \mathrm{v})$ sterile ferric hydroxide suspension or $1 \%(\mathrm{w} / \mathrm{v})$ sterile ferric chloride solution was added and the cultures incubated anaerobically for $24 \mathrm{hr}$. at $30^{\circ}$. Determinations of total iron in solution, ferrous iron in solution and $\mathrm{pH}$ value were made on the cultures. The results are given in Table 1 which show that the constituents of the cultures possessed virtually no capacity for iron reduction or iron solution unless untreated bacterial cells were present. 
Reduction of iron compounds by suspensions of washed bacterial cells

The first step was to determine some of the dehydrogenase systems present in cells of Bacillus circulans. The substrates tested and the times for complete reduction of methylene blue are given in Table 2, which shows that the washed cells contained active malic and glucose dehydrogenase, weak succinic and lactic dehydrogenase and no formic dehydrogenase.

Table 1. Solution and reduction of ferric compounds by 5-day cultures of Bacillus circulans after various treatments under anaerobic conditions. Determinations 24 hr. after the addition of iron compound

\begin{tabular}{|c|c|c|c|c|c|}
\hline & & & compou & led & \\
\hline $\begin{array}{l}\text { Treatment given } \\
\text { to 5-day culture }\end{array}$ & $\mathrm{FeCl}_{8}$ & $\mathrm{Fe}(\mathrm{OH})_{3}$ & $\begin{array}{r}\mathrm{FeCl}_{\mathbf{3}} \\
\mathrm{Fe} \\
\text { in } \\
(\mathrm{m}\end{array}$ & $\begin{array}{l}\mathrm{Fe}(\mathrm{OH})_{\mathrm{s}} \\
\text { iron } \\
\text { ion } \\
+ \text { /1. })\end{array}$ & $\begin{array}{c}\mathrm{Fe}(\mathrm{OH})_{\mathbf{3}} \\
\text { Total iron } \\
\text { in solution* } \\
\text { (mg./l.) }\end{array}$ \\
\hline Autoclaved & $5 \cdot 6$ & $6 \cdot 6$ & 1.5 & $\mathbf{0}$ & $\mathbf{0}$ \\
\hline Centrifuged & 4.7 & $6 \cdot 4$ & 0.5 & 1.5 & 2 \\
\hline $1 \mathrm{ml}$. chloroform & $6 \cdot 5$ & 6.5 & 0 & $\mathbf{2}$ & 2 \\
\hline Untreated & $6 \cdot 3$ & $6 \cdot 2$ & 20 & 25 & 27 \\
\hline
\end{tabular}

* Total iron only determined in tubes which received $\mathrm{Fe}(\mathrm{OH})_{3}$.

Table 2. Time for complete reduction of methylene blue by washed cells of Bacillus circulans in presence of various substrates

$\begin{array}{lc}\begin{array}{c}\text { Substrate } \\ (0 \cdot 01 \mathrm{M})\end{array} & \begin{array}{c}\text { Time for } \\ \text { complete reduction } \\ \text { (min.) }\end{array} \\ \text { Glucose } & \mathbf{9} \\ \text { Succinate } & 30 \\ \text { Malate } & 5 \\ \text { Lactate } & 50 \\ \text { Formate } & 60 \\ \text { Water } & 60\end{array}$

An attempt was made to reduce ferric hydroxide by washed cells in the presence of the substrates listed in Table 2. The Thunberg tubes and their contents were incubated for $1 \mathrm{hr}$. and then tested for ferrous iron with a $0.1 \%$ solution of $\alpha \alpha^{\prime}$-dipyridyl in $0.01 \mathrm{~N}-\mathrm{HCl}$. A very weak positive result for ferrous iron was given in those tubes which contained glucose. It was observed in other tests that when $\alpha \alpha^{\prime}$-dipyridyl was added initially, ferrous iron was detected quite readily in Thunberg tubes which contained ferric hydroxide; and $\alpha \alpha^{\prime}$-dipyridyl did not affect the time needed for methylene blue reduction. By using $\alpha \alpha^{\prime}$-dipyridyl in the iron-reducing system it was thus possible to compare the time for the appearance of ferrous dipyridyl with the time for complete reduction of methylene blue. The results of this comparison are given in Table 3. The times taken for the appearance of ferrous dipyridyl and for the complete reduction of methylene blue were correlated. The ferrous dipyridyl, however, appeared before the methylene blue was completely 
reduced. The intensity of the colour of ferrous dipyridyl in the various substrates increased with time; after $2 \mathrm{hr}$. it was inversely related to the time needed for complete reduction of methylene blue.

Table 3. Times for complete reduction of methylene blue and appearance of ferrous dipyridyl with washed cells of Bacillus circulans in various substrates

$\begin{array}{lcc}\begin{array}{c}\text { Substrate } \\ (0 \cdot 01 \mathrm{M})\end{array} & \begin{array}{c}\text { Time for methylene } \\ \text { blue reduction } \\ (\text { min. })\end{array} & \begin{array}{c}\text { Time for appearance } \\ \text { of ferrous dipyridyl } \\ \text { (min.) }\end{array} \\ \text { Glucose } & 14 & 13 \\ \text { Succinate } & 50 & 19 \\ \text { Malate } & 8 & 8 \\ \text { Lactate } & 99 & 80 \\ \text { Formate } & >120 & 90 \\ \text { Water } & >120 & 90\end{array}$

Table 4. Effect of various enzyme inhibitors on the time for methylene blue reduction and on the formation of ferrous dipyridyl in a washed cell +malate system

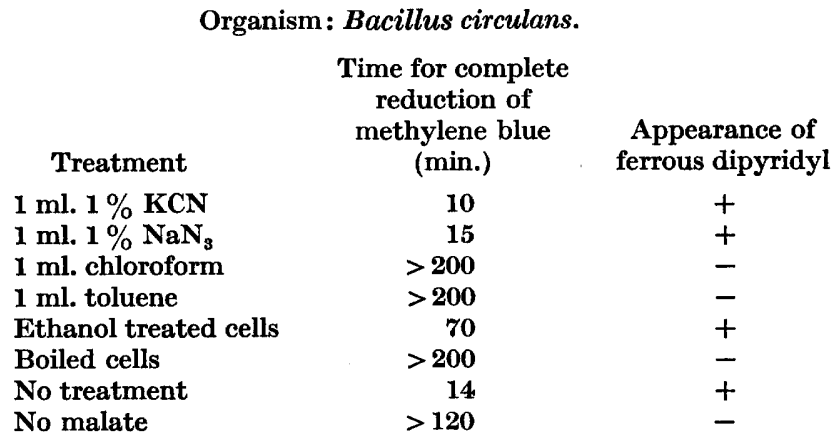

Effect of enzyme inhibitors on reduction

The effect of various enzyme inhibitors and of heat on the reduction of ferric hydroxide and methylene blue by washed cells of Bacillus circulans in the presence of $0.01 \mathrm{M}$-sodium malate was studied. The inhibitors used were: $1 \%(\mathrm{w} / \mathrm{v}) \mathrm{KCN}$ (giving a final concentration of $0.17 \%) ; 1 \%(\mathrm{w} / \mathrm{v})$ sodium azide; chloroform; toluene (these four substances were added in $1 \mathrm{ml}$. volumes directly to the rest of the solutions in the Thunberg tubes); $50 \%(\mathrm{v} / \mathrm{v})$ aqueous ethanol; the cells were treated for $30 \mathrm{~min}$. and then $1 \mathrm{ml}$. of ethanoltreated cells added to the Thunberg tubes. The heat treatment consisted of boiling the cell suspension for $2 \mathrm{~min}$.; then $1 \mathrm{ml}$. suspension was added to the tubes. The effect of these treatments is given in Table 4. The dehydrogenase inhibitors and boiling prevented iron reduction, whereas the poisons which did not inhibit or only partially inhibited the dehydrogenase system did not prevent iron reduction.

Reduction of ferric lactate by washed cells of Bacillus circulans

Ferric lactate prepared from $10 \mathrm{ml} .1 \%(\mathrm{w} / \mathrm{v})$ ferric chloride and $10 \mathrm{ml}$. of $10 \%(\mathrm{v} / \mathrm{v})$ lactic acid and neutralized with calcium carbonate to $\mathrm{pH} \mathrm{5.8}$ was 
used as the iron source in Thunberg tube experiments. The solution was used as soon as prepared; it did not give a reaction for ferrous iron with $\alpha \alpha^{\prime}$ dipyridyl. The treatments and results are set out in Table 5. The colour of ferrous dipyridyl was quite strong in tubes which contained fresh cells, malate or glucose, but very weak in the tubes without substrate and in those which received boiled cell suspension or no cells at all. Good reaction for ferrous iron was given immediately when $\alpha \alpha^{\prime}$-dipyridyl solution was added to tubes containing substrate + ferric lactate + fresh cells which had been incubated for as little as $10 \mathrm{~min}$.

Table 5. Reduction of ferric lactate by washed cells of Bacillus circulans

\begin{tabular}{|c|c|c|c|c|c|c|}
\hline \multirow[b]{3}{*}{$\begin{array}{l}\text { Substrate } \\
(0.01 \mathrm{M})\end{array}$} & \multicolumn{6}{|c|}{ Reaction for ferrous iron } \\
\hline & \multicolumn{3}{|c|}{$\alpha \alpha^{\prime}$-Dipyridyl added initially } & \multicolumn{3}{|c|}{$\begin{array}{c}\alpha \alpha^{\prime} \text {-Dipyridyl added after } \\
10 \mathrm{~min} . \text { incubation }\end{array}$} \\
\hline & $\begin{array}{c}\text { Fresh } \\
\text { cells }\end{array}$ & $\begin{array}{c}\text { Boiled } \\
\text { cells }\end{array}$ & $\begin{array}{l}\text { No. } \\
\text { cells }\end{array}$ & $\begin{array}{c}\text { Fresh } \\
\text { cells }\end{array}$ & $\begin{array}{c}\text { Boiled } \\
\text { cells }\end{array}$ & $\begin{array}{l}\text { No. } \\
\text { cells }\end{array}$ \\
\hline $\begin{array}{l}\text { Glucose } \\
\text { Malate } \\
\text { Water }\end{array}$ & $\begin{array}{l}++++ \\
+++t \\
+\end{array}$ & $\begin{array}{l}- \\
-\end{array}$ & $\begin{array}{l}- \\
- \\
-\end{array}$ & $\begin{array}{l}++++ \\
++++ \\
+\end{array}$ & $\begin{array}{l}- \\
- \\
-\end{array}$ & $\overline{-}$ \\
\hline
\end{tabular}

Effect of ferric hydroxide, ferric lactate and sodium lactate on methylene blue reduction

To determine the effect of ferric hydroxide, ferric lactate and sodium lactate on the time for complete reduction of methylene blue by malic dehydrogenase, Thunberg tubes were set up as follows. Each tube contained malate + cells + calcium carbonate and either $1 \mathrm{ml} .1 \%(\mathrm{w} / \mathrm{v})$ ferric hydroxide suspension, or $1 \mathrm{ml}$. ferric lactate solution (see above), or $1 \mathrm{ml} .5 \%(\mathrm{w} / \mathrm{v})$ sodium lactate or $1 \mathrm{ml}$. water. The times for complete reduction were $5,60,5$ and $5 \mathrm{~min}$. respectively. At the end of this experiment the various tubes were tested for ferrous iron; only those which had received ferric lactate gave a positive reaction. These results indicate that lactate and ferric hydroxide have no effect on the time for complete reduction of methylene blue by malic dehydrogenase, whilst soluble ferric iron considerably delays the reduction time.

Reduction of iron compounds by washed cells of Bacillus megaterium and Aerobacter aerogenes

It was found previously (Bromfield, 1954) that growing cultures of Bacillus megaterium and Aerobacter aerogenes were, respectively, poor and fairly good reducers of ferric hydroxide in medium $A$ when compared with $\boldsymbol{B}$. circulans. Experiments similar to some of those described above for the washed cells of $B$. circulans were carried out with cells of these other two bacteria. It was found that their cells, in the presence of a suitable dehydrogenase substrate, behaved similarly to cells of $\boldsymbol{B}$. circulans.

\section{DISCUSSION}

The mechanisms for the reduction of ferric compounds by bacteria and by sterile plant extracts differ (Bloomfield, 1951, 1953) since the culture fluid of Bacillus circulans does not reduce these compounds unless untreated cells are 
present (Table 1) whereas sterile plant extracts do. The reduction of ferric iron by the bacteria examined appears to be closely associated with dehydrogenase activity for the following reasons: $(a)$ the time for methylene blue reduction is comparable to the time for the appearance of ferrous iron in the presence of an active dehydrogenase (Table 3); (b) the dehydrogenase inhibiting treatments (Table 4) which prevent methylene blue reduction also prevent iron reduction; (c) soluble ferric iron increases the time required for complete reduction of methylene blue when the two are mixed.

An active dehydrogenase system, however, is not enough in itself to cause reduction of ferric hydroxide, since ferric iron is only reduced by such a system when the iron is in solution or when there is a complex-forming substance such as $\alpha \alpha^{\prime}$-dipyridyl present. These relations may explain why some growing cultures of bacteria reduce ferric hydroxide more than others (Bromfield, 1954). These differences may be due to the production of variable amounts of specific organic acids or complex-forming substances which affect the solubility of ferric hydroxide. If this be so then iron reduction should occur when substances are formed which can increase the solubility of ferric hydroxide without interfering with the maintenance of active dehydrogenase systems.

A mixed culture of bacteria might reduce ferric hydroxide more readily than a pure culture of any one organism of the mixture. Bacterial reduction may be important in increasing the nutrient availability of iron and manganese oxides and also in determining the movement of iron and manganese in soil profiles, especially where there is abundant available organic matter.

The author wishes to acknowledge the financial support of the C.S.I.R.O., Australia, for making this research possible and the assistance of the Bacteriology Department, University of Melbourne, in providing facilities for the continuation of these investigations in Australia. Thanks are due to Dr H. G. Thornton, F.R.S., and to $\mathrm{Dr} \mathrm{N}$. Walker for their criticism and advice during the early stages of the work.

\section{REFERENCES}

BÉtrémieux, R. (1951). Étude expérimentale de l'évolution du fer et du manganèse dans les sols. Ann. Agron., Paris, 2, 198.

Bloomfield, C. B. (1951). Experiments on the mechanism of gley formation. J. Soil Sci. 2, 196.

Bloomfield, C. B. (1953). A study of podzolization. J. Soil Sci. 4, 5.

Bromfield, S. M. (1954). The reduction of iron oxide by bacteria. J. Soil Sci. 5, 129.

Halvorson, H. O. \& Starkey, R. L. (1927). Studies on the transformations of iron in nature. Part II. Concerning the importance of micro-organisms in the solution and precipitation of iron. Soil Sci. 24, 381.

PIPer, C. S. (1942). Soil and Plant Analysis. Adelaide: Hassell Press.

Quastel, J. H., Stephenson, M. \& Whetham, M. D. (1925). Some reactions of resting bacteria in relation to anaerobic growth. Biochem. J. 19, 304.

Roberts, J. L. (1947). Reduction of ferric hydroxide by strains of Bacillus polymyxa. Soil Sci. 63, 135.

(Received 8 October 1953) 